\title{
Variation and change in contact settings
}

\author{
Isabelle Léglise and Claudine Chamoreau \\ CNRS, SEDYL-CELIA
}

\begin{abstract}
This paper introduces two linguistic fields dealing with language change: contact linguistics and sociolinguistic research on variation. It argues that although there is no language change without variation, linguistic variation is still an opaque area, a blind spot, for most contact-induced language change studies. The role of variation in changes occurring in multilingual settings has not been much discussed in the literature and the exact role and interplay of the notions of 'variation', 'change' and 'contact' have not yet been fully explored. This paper proposes to examine more precisely the relationship between variation and change in language contact settings.
\end{abstract}

Keywords: ongoing variation, contact induced change, contact settings

Contact linguistics (Thomason \& Kaufman 1988; Thomason 2001a; Winford 2003; Heine \& Kuteva 2005), like historical linguistics, has a tradition of exploring stable contact settings. From its beginnings (Weinreich 1953), stable and diglossic settings have been the subject of study. The literature focuses either on the diachronic changes that have appeared in some historical settings or on the completed changes that gave rise to current situations and linguistic forms. For example, in their collection of articles on the structural effects of language contact, Matras \& Sakel (2007: 1) explicitly note that they asked each contributor "to focus on the diachronic impact that language contact has had on the structure of a particular language." Since not much social data - or different types of data - for these historical settings are usually available, studies in contact linguistics have generally focused on diachronic linguistic results ${ }^{1}$ at the expense of exploring either social processes or linguistic phenomena such as variation and ongoing change. It is rare to find studies that investigate

\footnotetext{
${ }^{1}$ This does not mean ignoring social data. Historical linguistics and contact linguistics both add some contextualization to their data, but it is not their main focus. For example, in the Matras \& Sakel collection cited, the introductory sections of each chapter were required to include "comments on societal multilingualism, the roles that are assigned to various languages in the community, patterns of language mixing, and issues of language policy and language education.”
} 
synchronic contact settings or ongoing variation involving several languages at once.

In contrast, sociolinguistic research on variation has from its beginning mostly focused on monolingual population even if the speech communities under consideration were heterogeneous and socially and linguistically diverse. The pioneering studies on social stratification in New York (Labov 1966, 1972) or social differentiation of English in Norwich (Trudgill 1974) excluded non-native speakers of English, they focused on intra-varietal change and did not examine "the effects of contact" (Labov 1994: 20). On the other hand, other lines of research have focused on multilingualism and code-switching (Fishman 1967; Gumperz 1982; Myers-Scotton 1993a, 1993b; Auer 1995, 1998, 1999; Muysken 2000 among others), or second language acquisition (Bayley \& Preston 1996). It has been difficult to integrate the results of these different lines of research, perhaps because it is widely assumed that the "variability found in bi- and multilingual speech communities is more extensive than that found in monolingual and majority-language communities” (Sankoff 2002: 640). According to Sankoff, the description of a bilingual community "involves more social parameters, more daunting inter-individual variation and major sampling and other methodological problems.” This complexity might well explain the relative lack of published research (but see Meyerhoff \& Nagy 2008), except in the sub-field of dialects in contact (Gumperz 1958; Trudgill 1986; Siegel 1987; Mesthrie 1993; Kerswill \& Williams 2000; Auer, Hinskens \& Kerswill 2005 etc.).

Nonetheless, given the creative nature of language activity (Coseriu 1958) and the creative nature of language change (Lehman 1985) most studies of language contact settings include evidence of linguistic change and sometimes also evidence of synchronic variation; but the exact role and interplay of the notions of "variation," "change," and "contact" have not yet been fully explored. It is the chief goal of this book to examine the relationship between variation and change in language contact settings. A secondary goal is to bring together different research traditions to bear on this subject and to explore the same connections.

After proposing some initial thoughts on the issues at stake, we introduce two main aspects of this relationship, as presented in the contributions to this volume. The first part of the volume is devoted to the study of different instances, types, and outcomes of variation and change within contact settings; the second part focuses on the possible causes of ongoing linguistic variation in those settings and the role of ongoing variation in contactinduced language change. 


\section{Variation and the mechanisms of language change}

Language contact is typically responsible for morphosyntactic variation (sometimes simply called "change" in the literature) in the languages that are in contact. It often leads to competition between an innovative and a previously existing form or structure. This competition seems to be chiefly responsible either for free variation, or for a new functional distinction between the "new" and the "old" form, or for the abandonment of the "old" form. From a comparative or functionalist perspective, all three of these may be called change.

For some authors, when an innovative form or structure appears or already exists it constitutes a change in the linguistic system. Stolz (2006: 15), for example, defines the notion of (contact-induced) typological change: "For typological change to occur in a language $\mathrm{A}$, two chronologically different stages $\mathrm{T} 1$ and $\mathrm{T} 1+\mathrm{n}$ of $\mathrm{A}$ are required with $\mathrm{A}$ displaying properties of typological class $\mathrm{X}$ at $\mathrm{T} 1$ and properties of a typological class non-X at $\mathrm{T} 1+\mathrm{n}$. This definition allows for the possibility that non-X properties may not have ousted $X$ properties at stage $\mathrm{T} 1+n$, i.e., in lieu of a full-blown change from one typologically-defined class to another, language A combines the characteristic traits of more than one typological class at the same time." For others, a second process is needed before the phenomenon can be properly called change - the propagation or diffusion of the innovation. Croft (2000: 185), for example, says that "language change consists of two processes: altered replication of a replicator, i.e. innovation; and differential replication of replicators leading to survival/extinction, i.e. propagation.” And lastly, for a minority of authors who adopt this paradigm, not only are diffusion or propagation necessary, but the stability of the system also enters into consideration. For example, depending on their time-frame and stability, contact-induced changes may be seen as completed if "some aspects of the grammatical system of a language do not show any synchronic variation and speakers are hardly aware of these as 'foreign"," and "the contact is now in the past" (Aikhenvald 2006: 21). Alternatively, contact-induced changes may be seen as "in progress," "ongoing," or "continuous" (Tsitsipis 1998) when "the degree of influence of the other language depends on the speaker's competence and proficiency” (Aikhenvald 2006: 22).

From a variationist perspective, synchronic variation is a prerequisite for diachronic change and a characteristic of living languages, and while all three types of change just listed could be called "change in progress," only the last, at a later stage, can indubitably be called a "completed change." Since Weinreich et al. (1968), a considerable body of evidence has confirmed that variation in language and in language use is the norm rather than the exception. Labov's work on the mechanism of change has strikingly demonstrated that patterns of variation are crucial for 
understanding how change takes places and what drives it (as in his Martha's vineyard pioneering study), even though variation (which is defined as a first stage and plays a role in the long term) does not necessarily lead to "completed" change. Only occasionally does a "new" or innovative form survive for long enough, spread (in the second stage of diffusion), and possibly lead to regularity and to the abandonment of the "old" form.

The S-curve model is largely accepted as representing the transmission and propagation of a linguistic innovation (Aitchison 1991; Labov 1994; Croft 2000; Kroch 1989; Denison 2003). In its ideal manifestation, the innovative form spreads slowly at the beginning, then becomes rapidly more and more frequent before the process slows down considerably, just before reaching completion. The new form, now seen as acceptable and stable, is conventionalized.

Labov (1972) and his followers essentially focused on the propagation or diffusion of linguistic variants, the stage of change when linguistic forms in competition take on social signification. The earliest studies concentrated on social signification in terms of (overt) prestige vs. lack of prestige. If the innovative form emerges from a non-dominant social group, the social value given to the form may be overtly low. ${ }^{2}$ The innovative form may then be stigmatized by the dominant social group and subject to correction in formal discourse. If a variant is violently stigmatized, the innovative non-standard form may disappear. But the same may apply to linguistic forms seen as indicative of the upper class or would-be members of the upper class, such as yuppies in the 1980s (Chambers \& Trudgill 1980), which also tend to be abandoned. The development of studies on social networks, starting with pioneering work on linguistic variation in Belfast, opened up new ways for working on the diffusion of change (Milroy \& Milroy 1993; see also Beyer \& Schreiber, this volume), since a major objective of the variationist perspective is to "specify how languages pass from state A to state B in terms of both the social processes involved and the effect on linguistic structure of a given change" and "to develop a theory which is sensitive both to the constrained and regular nature of change and to its relationship with social structure” (Milroy \& Milroy 1985: 339). Speakers take part in their social environment through a network consisting of ties of varying strength and density depending on the social bonds they possess. A speaker's innovation may fail to diffuse beyond the speaker, or it may diffuse into a community (through the speaker's social network) and then diffuse from that community into other communities via a further innovator who has ties with both the relevant communities. "When the results of this process are observed, we tend to label the results as "linguistic change"”

\footnotetext{
${ }^{2}$ Though not always, as when the stylistic practices of young people gain covert prestige and become popular.
} 
(Milroy \& Milroy 1985: 347). The Milroys’ work showed the roles that both innovators and early adopters play: they demonstrated that innovations are transmitted from one group to the another by persons who have weak ties with both groups, and that at the macro-level, in situations of mobility or social instability, where the proportion of weak links is high, linguistic change is likely to be rapid. ${ }^{3}$ Other implications of the Milroys' work on vernacular speech in Belfast concern the relationship between standard and vernacular norms, stressing the uniform nature of the standard and the essentially variant structure of vernaculars, where rules governing the variation are understood by those within the vernacular community but not those outside it.

The beginning and end of the change process are also critical points. Long-term change over centuries has been documented in which the "old" or "archaic" form is still used (such as the passive progressive in English, ${ }^{4}$ discussed in Denison 2003 and Desagulier 2005), meaning that we cannot consider the process as now at an end (Trudgill 1999). It is also very difficult to determine when a form entered the grammar of a language, as Israel notes in the case of way-constructions in English: "The wayconstruction emerged gradually over the course of several centuries. There is no single moment we can point to and say, 'This is where the construction entered the grammar.' Rather, a long process of local analogical extensions led a variety of idiomatic usages to gradually gain in productive strength even as they settled into a rigid syntax” (Israel 1996: 227).

Finally, there are cases in which long-term variation does not lead to change at all. A variant may remain alongside others for a long time, even centuries. Cases in point are described by Béniak \& Mougeon (1984) for long-term variants such as French à vs. de, where à is used in nominal groups marking possession or belonging instead of the standard form de. Both forms still exist alongside each other. Another case in point is that discussed by Valli (2001) on the possessive dative in French: ${ }^{5}$ he shows that

\footnotetext{
${ }^{3}$ But see Labov's work on Philadelphia where he showed that weak ties are important for innovation to take place, but its spread requires strong ties, that is someone who is the star of a network but at the same time maintains regular contacts outside of the network.

${ }^{4}$ At the end of the eighteenth century, constructions such as "a road was being built" replaced "a road was building." But the last construction, though seen as archaic, has not completely disappeared.

${ }^{5}$ These are dative constructions not selected by the verb valency, as in "On lui a coupé les cheveux," where in standard French the referent of the dative pronoun indicates the possessor of an inalienable entity as a body part. Other examples in contemporary (nonstandard) spoken French, such as "Il lui a drôlement arrangé sa voiture,” or "ma mère elle avait une colère on y avait cassé au moins deux ou trois vitres," show that the dative possessive may be expressed as a pronoun or as a noun and that the possessed nouns may be other than body parts, as in Old French "Tout son haubert li a faussé / le cuir li trenche sor le pis: il lui a détruit son haubert / la peau lui trenche au-dessus de la poitrine).” As in
} 
contemporary non-standard usage is similar to old French usage and contrary to contemporary standard French. This variation still exists and has not led to a change in the norm or in the standard.

The above discussion does not deal with contact settings. Although there is no language change without variation, linguistic variation is an opaque area, a blind spot, for most contact-induced language change studies. Attempting to eliminate this opacity is one goal of this book. We believe that looking closer at variation in the field of contact-induced language change will increase our understanding of language change overall. Bringing together different backgrounds may then permit cross-fertilization between various lines of research. Consequently, we start by presenting two analyses within the variationist framework before discussing the relationship between internal variation and contact-induced variation and change.

\section{Types and outcomes of variation in multilingual settings}

The first part of this volume is devoted to the study of different instances, types, and outcomes of variation in multilingual settings. In the first chapter, Miriam Meyerhoff introduces linguistic variation, specifically contactinduced language variation, from a variationist point of view, including the diffusion of variants and the use of statistical tools to study it. For example, a close examination of constraints on variation using statistical tools provides clues for distinguishing different processes of transfer. She shows that the comparison of subject and object expresson in Bislama, an Englishlexified Creole, and Tamambo, a conservative Eastern Oceanic language, looks like a case of what she calls strong transfer. A multivariate analysis using Goldvarb reveals that for Tamambo subjects only two factors exert a significant constraint on the alternation between pronoun subjects and null subjects: the discourse status of the referent and the animacy of the referent. With regard to Bislama, Meyerhoff (2000) showed that the principal constraints on the expression of Bislama subjects as pronouns or as null subjects are the person and number of the subject (where agreement on the verb is more transparent, a null subject is more likely) and its discourse status in the preceding clause. Animacy proved also to be a significant constraint. Comparing the ranking of factors constraining variation in Bislama and Tamabo shows that the same types of factor do play a role. Meyerhoff therefore distinguishes three different transfers in terms of their behavior in response to constraints of variation. A weak transfer or replication in the sense of Heine \& Kuteva (2005) occurs when the same general constraints are significant in Language A and Language B but their

Old French, the contemporary non-standard usage is less restrictive than the current normative usage and both variants still exist. 
relative strength may differ. A strong transfer occurs when the same general constraints are significant in Language A and Language B, and their relative strength is the same in both languages. Lastly, there occurs what she calls calque or calquing in instances in which everything is transferred, that is, where there is the same weighting of factor groups in both languages and the same weighting of factors within groups. She suggests that calquing is quite rare, especially where the start or end point is a variable linguistic phenomenon. This may be because the process of transfer encourages the transformation of the input, sometimes to the extent of complete reversal of its valency in the two languages, as in the case of Tamambo and Bislama.

Hélène Blondeau examines a change currently under way in French, namely the variation among on 'one', $t u$ 'you,' and vous 'you' to express an indefinite reference, in relation to Quebec languages in contact dynamics. Her variationist analysis is based on corpora of spoken French that represent different dimensions of contact between French and English in Quebec. A comparison between nineteenth- and twentieth-century Québecois French data reveals that the use of second-person pronouns as indefinite pronouns, although frequent in a twentieth-century sociolinguistic corpus, was rare in the corpus representing an earlier stage of the language and a less intense contact situation. This analysis tends to confirm that the change in favor of second-person pronouns is a very recent phenomenon, since no evidence of a productive use of indefinite second-person pronouns is found in the nineteenth-century data. However, this difference could also be due to differences in the interactional dynamics of each body of data. However, comparison of the linguistic behavior of bilingual Anglo-Montrealers with that of native speakers of French in Montreal offers striking similarities; it reveals that their use of the second-person indefinite not only moves in the same direction as the current ongoing change in favor of second-person pronouns observed for L1 speakers at the end of the twentieth century, but actually pushes the change forward in their own repertoire. This analysis sheds light on the question of the behavior of the L2 speaker in the case of a variable that is undergoing change in the target language, a question that has not received enough attention until now (but see Migge \& Léglise 2011).

These two chapters discuss monolingual data and their relation to variation and language contact. The next two directly address issues of the spread of innovation within a multilingual context. Zabrodskaja deals with mixed corpora exhibiting instances of code-switching between Russian and Estonian. She questions the role and effects of code-switching on the spoken Russian variety, with reference to the Matrix Language Frame (MyersScotton). Beyer and Schreiber address the outcomes of contact between two African languages, Samo and Pana, using a reconstructed diachronic scenario of contact and social network theory (Milroy) in a very innovative way. 
Anastassia Zabrodskaja describes some morphosyntactic innovations in Estonian Russian by analyzing code-switching in Estonia as spoken by two groups of young Russian-speaking students, one in bilingual Tallinn and the other in the predominantly Russian-speaking northeast. She studies the spread of two types of innovation in conversational speech. First, she looks at lexical borrowings (mainly NPs or established expressions that belong to the university domain) in the speech of Russian-speaking students. In her corpora, many Estonian nouns have reached the stage where the borrowings have superseded the Standard Russian equivalents, while others still occur alongside the Russian nouns. She shows that such borrowings are internationalisms and/or bilingual homophones that facilitate codeswitching, or what Clyne (1987) calls "lexical facilitation" or "triggering." In the literature, there is no clear consensus about when something should count as lexical borrowing and when as code-switching (Lauttamus 1991; Thomason 2001a). This debate is clearly related to our various conceptions of what a language is $v s$. what a linguistic repertoire is, and what we believe distinguishes variation from change.

Second, Zabrodskaja analyzes examples of Russian genitive constructions containing code-switching and using Estonian word order, ${ }^{6}$ in situations where the MLF model (Myers-Scotton 1993a, 1993b) would predict the Russian word order and the Equivalence Constraint (Poplack 1980) would prohibit code-switching. She shows that they are an instance of a specific convergence (no Estonian-language morphemes are employed, but the underlying structure is clearly Estonian), and proposes the term "unidirectional structural change" for the situation in which Estonian provides the word order and Russian provides lexical items. Other mixed constructions of the type noun + noun or verb + verb are viewed as instances of congruent lexicalization (Muysken 2000), that is, where the vocabulary comes from two languages and both languages jointly provide the grammatical structure of the clause. She describes the role of codeswitching in variation and change: common internationalisms activate convergence of the Russian grammar system with Estonian through congruent lexicalization; these nouns facilitate code-switching and lexical borrowing, influencing morphosyntax on the phrase level at the same time; thus mixed constructions and (later on) congruent lexicalization occur. Code-switching triggers convergence, which, in turn, can trigger another switch. Lexicosyntactic convergence facilitates code-switching even further, because overlapping syntax can act as a secondary facilitator. We see that code-switching causes changes which, in turn, increase similarities and facilitate code-switching. "The more code switching, the more congruent lexicalization; the more congruent lexicalization, the more convergence; the

\footnotetext{
${ }^{6}$ A monolingual Russian word order is NOUN INSTR + ADJ GEN + NOUN GEN; code-switching follows the monolingual Estonian word order ADJ GEN + NOUN GEN + NOUN INSTR .
} 
more code switching, the more overlapping occurs and, in turn, the more code switching takes place, in a kind of snowball effect" (Thomason 2001b).

Klaus Beyer and Henning Schreiber investigate the outcome of contactinduced language change in two neighboring speech groups (Pana and Northern Samo) in an African multilingual setting. They identify linguistic innovation by comparison with the respective reconstructed proto-systems and by dialect comparison, seeking to establish whether such innovations should be regarded as contact-induced or as independent internal developments. What is innovative is that this approach is combined with a sociolinguistic analysis of social networks. It serves both as a descriptive ethnographic attempt at capturing socially relevant categories and factors and as a way to model the spread of linguistic innovation within the speech community. It also illuminates the linguistic consequences of speech-group events. It is clear that the degrees and motivations of multilingualism among the different speech-groups are multiple, uneven, and varying in source. Although the overall setting is the same, there are differences between the speech communities under consideration. Beyer and Schreiber had already developed some ideas about the innovative profile of those speakers who act as driving forces of contact. However, the mechanisms of the spread of innovation are still obscure, since foreign elements are also used by noninnovative actors. Looking at the sociolinguistic conditions, the authors argue that multiple speech-group events have favored the weakening of social ties and hindered the preservation of linguistic norms. This seems to be in accordance with Milroy's network model, in which similar social settings favor change and lead to a high innovation rate (2001). They demonstrate that morphosyntactic elements such as negation, copula, and focus constructions, phrase-final plural, and definiteness marking are in part the result of contact in this complex setting. They examine a working hypothesis about the speech-group events (Ross 1997) and social characteristics that produced and still produce the convergence phenomena in the two languages. Lastly, they raise the general question of the significance of extra-linguistic parameters in such a study and, more specifically, how to incorporate ethnographic information and speech-group events into the explanation of contact-induced language change.

Beyer and Schreiber argue that contact-induced changes in the two speechgroups under investigation are as complex as the socio-historical setting in which they appear. Linear models in the contact linguistics field, such as a borrowing scale (Thomason \& Kaufmann 1988), seem not to explain the complexity of the changes that occur; one example is the correlation between time of contact, societal types, and speech-group size on the one hand and contact-induced linguistic outcomes on the other, which is commonly proposed in the literature (Nichols 1992; Thomason 2001a; Trudgill 2004; Winford 2003; among others). Beyer and Schreiber show 
that few linguistic parameters are able to withstand processes of convergence in a long-lasting and intense contact situation. Parameters like mobility and kinship ties, resulting from the socioeconomic situation in the region, lead to multilingualism and thus the spread of changes. In their case changes cannot be classified unequivocally in terms of increase or decrease in linguistic complexity; this is comparable to the observations of Migge \& Léglise (2011) of simplification and diversification in French Guiana and Suriname among Eastern Maroon communities. Both directions are observable here and cannot be correlated with specific societal types or speech-group sizes.

Beyer and Schreiber conclude that for the time being the development of an integrated model of contact-induced language change that would take all the different aspects of historical and social factors into account is a very ambitious project.

\section{The role of ongoing variation in contact-induced change}

Language contact can be responsible for innovation and linguistic variation. However, ongoing variation often pre-dates contact, and very often it is hard to tell whether linguistic variation in contact settings is due to contact, to internal linguistic processes, or to both. This section investigates in more detail the role of ongoing linguistic variation in contact settings and language change. Is the role of variation in contact settings the same as in traditional internally generated change (that is, from a variationist standpoint, does variation always precede change)? What impact does language contact have on existing social or dialectal varieties, and what is the influence of language contact on previous variability (that occurring prior to contact)? Pakendorf shows, for example, that internal variation may be necessary before new categories can develop under the influence of contact: that is, it has to provide the forms for any new category. In many cases, language contact seems "only" to increase the frequency of occurrence of an already existing variant (Blondeau, Léglise). Does contact always have a "snowball effect" (Thomason 2001a) on pre-existing variation?

The role of variation in changes occurring in multilingual settings has not been much discussed in the literature. Raising questions about it here does not imply that we view it as prominent in contact-induced change. But we do not accept the "If-in-doubt-do-without" assumption (Farrar \& Mari Jones 2002), the belief that "the majority of changes a language undergoes are due to internal factors, and that therefore we should first concentrate on identifying these internal causes of change. Only if this proves unsuccessful, the argument runs, should we then widen our search to consider external or extra-linguistic motivating factors. Examining whether contact plays a role 
in change is therefore seen as a last resort, and 'if in doubt' we should 'do without' and simply not take this final step" (2002: 4). ${ }^{7}$ And "Another important issue inherent in the 'If-in-doubt-do-without' mentality is whether internal factors play a more frequent role than external ones in motivating change. There is an assumption that the majority of changes that occur in a language are due to characteristics of the linguistic structure it has inherited. The strong influence wielded by the family tree model of genetic development is partly responsible for this” (Farrar \& Mari Jones 2002: 6).

In sharp contrast, in contemporary contact settings where language contact and multilingualism are clearly present, as described in Léglise's chapter, it is often argued that variation (in Language A) is due to language contact (or linguistic transfer from Language B). Especially in situations where a Creole language is in contact with its erstwhile lexifier, such variation is often seen as due to a specific language contact setting and producing specific results, ${ }^{8}$ namely either decreolization of the Creole (even if the notion originally proposed by De Camp (1971) is being challenged, see Mufwene 2001, Aceto 1999) or else a new creolization / re-creolization of the European language (Winford 1997). The same "If-in-doubt-do-without" mentality is at work, but in reverse: there is a general assumption among sociolinguists and creolists that the majority of changes are due to language contact. This assumption masks the fact that each factor may play a role.

Isabelle Léglise argues that in multilingual settings - and especially where a Creole language is in contact with its erstwhile lexifier - instead of looking only for an explanation involving contact, we have also to consider the role of inherent tendencies in the various languages involved. If the linguistic outcomes can be explained both by inherent tendencies and by language contact, which usually seems to be the case when we invoke "multiple causation" (Thomason \& Kaufman 1988), this still leaves us with the task of determining the exact role each of these may play. Taking examples of standard and non-standard variations in the French spoken in French Guiana (in contact with Guianese Creole), Léglise demonstrates the interplay of different linguistic factors - linguistic and typological tendencies and contact-induced transfer. She takes the example of the object clitics in spoken French, treating the pronominal system as a particularly non-stable domain specific to French and other Romance languages, given that many variations are observed over space and time in the paradigm. Speaking of "particularly non-stable domain" is a slightly different position than the one

\footnotetext{
${ }^{7}$ Thomason \& Kaufman (1988: 57-59) note that "historical linguists have traditionally been strongly prejudiced in favor of internal explanations for linguistic changes. In particular, the methodological inclination has been to consider the possibility of external causation only when all efforts to find an internal motivation for some change have failed (Martinet 1955: 194) ... multiple causation is rarely suggested."

${ }^{8}$ See Goury \& Léglise (2005) for a discussion of this.
} 
expressed by Meillet (1912), who wrote of the "fragility" or "weak points of the linguistic system," (see discussion by Béniak \& Mougeon $(1984,1989)$ and Chaudenson (1986)) or Houdebine (1985), who wrote of "stable and non-stable co-existing structures in a language”. Anyway, giving that certain linguistic domains include lots of variations and linguistic variables (Meyerhoff, this volume), Léglise (2007) has suggested that these nonstable domains are more likely to undergo change and restructuring when languages are in contact, as some morphemes or constructions are more "vulnerable" (Matras 2007) than others to language contact.

In this volume, Léglise describes a mechanism of ongoing variation and the combination of different explanatory factors in the linguistic outcomes she observes. She shows first that clitic variation is due to an inherent tendency within French to the reduction of paradigms. In a second stage, this tendency encounters the system of French Guianese Creole (a reduced pronominal paradigm), creating a "snowball effect" (Thomason 2001a) that reinforces the inherent tendency. Consequently, the present-day language contact situation produces a higher frequency of variation; it increases the productivity of variation and spread of innovative forms within a specific grammatical domain in contact settings, which is a phenomenon slightly different from but related to "activation" (Clark 1994), "enhancement" (Aikhenvald 2006: 22), and "frequential copying” (Johanson 2002). Finally, Léglise argues that one specific pronoun (the third-person object ${ }^{9}$ ) is especially affected by the changes in progress because it has a larger number of forms in the paradigm than the other pronouns.

Azucena Palacios also looks at changes that occur in already unstable and variable areas of a language's grammar, focusing primarily on pronouns in another Romance language, Spanish. She discusses changes in American Spanish that are attributable to both internal and external factors. The changes she is interested in originate in "pre-existing internally caused variation" in the language. In these cases, the contact language (an Amerindian language such as Quechua or Guarani) acts as an accelerator of the variation process, producing change at least in colloquial oral registers.

Palacios claims that the resulting patterns in those contact settings diverge from the outcome to be expected from internally generated changes; she then differentiates the two processes in terms of the origin of the morphosyntactic materials involved and the results of the changes. In intense contact settings, contact-induced changes "due to the instability or vulnerability of certain grammatical areas already subject to pre-existing internally generated linguistic variation” produce different results from "those of contact-induced changes in which morphosyntactic material from outside the language is imported or morphosyntactic structures are replicated in the sense of Heine \& Kuteva (2005). The latter do not require

\footnotetext{
${ }^{9}$ Singular indirect lui vs. direct le/la ; plural indirect leur vs. direct les.
} 
previous internal variation, since any structure can be replicated and any morpheme incorporated into a language under intense contact, as happens in Paraguayan Spanish." Their consequences are "unexpected" or "more innovative, ... going beyond the predictable outcome" of internally generated change; they can include the reorganization of an entire paradigm (unstressed pronouns as in Paraguay and Andean Ecuador), the acceleration of a change in progress and the removal of linguistic restrictions on it (direct object elision), and the assignment of new values to already existing structures (adoption of epistemic values by the preterit tenses in the Spanish of Andean Ecuador).

When the contact-induced changes do not involve the importing of morphosyntactic material or structures, Palacios argues, the changes follow systematic patterns conditioned by the structures of the languages involved in the contact situation.

Taking examples from several northern Eurasian languages such as Sakha (a divergent Turkic language spoken in Siberia), Evenki (a Northern Tungusic language), and some Mongolic languages, Brigitte Pakendorf presents evidence for the important role played by language-internal variation in situations of contact-induced change through two different processes. The first of these, also mentioned by Blondeau, Léglise, and Palacios, is known as "frequential copying" or "enhancement." This refers to a shift in the frequency of use of variant constructions, as discussed by Johanson (2002: 306), Aikhenvald (2002: 238), and Heine \& Kuteva (2005: 44-62): “A widely observable process triggered by language contact concerns infrequently occurring, minor use patterns that are activated because there is a model provided by another language" (Heine \& Kuteva 2005: 50). In frequential copying, an infrequently used construction in the recipient language can increase in frequency and ultimately even become the norm, if there is a similar construction in the model language. In the cases studied by Pakendorf, two variants of a construction exist side by side and fulfill roughly the same function: this is true for the variation in possessive constructions documented in Old Turkic, the variation in local case functions in the Tungusic languages, and the variation in subject agreement marking on finite verbs in historical written Mongol texts. In such cases, a shift in frequency of use leads to the establishment of one variant rather than the other as the norm within the speech community - without, however, leading to any change in meaning. Thus, she argues, language-internal variation plays an important role in contact-induced language change by providing access to constructions that can be activated by exposure to the neighboring language.

A second way in which ongoing variation can interact with contact is by providing the material basis for grammaticalization processes that are triggered by structures found in the contact language. The process by which existing forms are taken over to fulfill different functions from their original 
ones is called "contact-induced exaptation" by Pakendorf. She uses the term as proposed by Lass (1988), "the opportunistic cooptation of a feature whose origin is unrelated to its subsequent use" (Lass 1988: 34), with a broader meaning that applies in the case of the imperative in Sakha. The material co-opted to create the future imperative was already in use as an imperative construction, and Pakendorf notes the co-optation of this preexisting form to fulfill a new function: a periphrastic construction with a pragmatic function has been taken over to create a temporal distinction between a present and a future imperative. She argues that in situations of language contact, bilingual speakers reinterpret the meanings of forms on the basis of their perceived correspondence to a form in the model language, that is, by "interlingual identification" (Weinreich 1953: 7-8). Here, the identification of the recipient language variant with the model language construction leads to its reanalysis.

She concludes by noting that variation plays an important role in contactinduced change, although it would be going too far to claim that variation is a necessary prerequisite of such change, given that languages very frequently copy forms they lack.

Multiple causation in linguistic change has long been asserted, especially in contact settings, and the need for adequate models has long been noted (Malkiel 1967; Thomason \& Kaufman 1988), ${ }^{10}$ even before the flowering of multiple causation analysis (Joseph 1981; Schwegler 1983, etc.) ${ }^{11}$ and the appearance of models and frameworks explicitly devoted to multiple causation (Thomason 2001a; Aikhenwald 2006), followed by analysis drawing on multi-model approaches to contact-induced change (Chamoreau \& Léglise 2012). All the authors here draw on complex theoretical models to explain language change in contact settings, some of them explicitly identified as multiple causation models. In her discussion of Pomak, a language spoken in Greece, Evangelia Adamou adopts a multiple causation approach to studying the loss of a morphologically overt expression of mediate information, passing through a stage of ongoing variation. She provides examples of the catalyst role played by language contact. This change takes place in a trilingual setting where the main contact language (Greek) has no grammaticalized form to express mediate information, while the second contact language (Turkish) has a verbal past paradigm specialized for evidentiality.

Adamou highlights the roles of different causal factors: with regard to sociolinguistic factors, the loss of the oral tradition is obviously related to the loss of the grammatical forms (such as the auxiliary) specialized in

\footnotetext{
10 “Concomitant circumstances may have accelerated the process at issue or have increased the likelihood of the event under study; yet a formal, systematic high-level inquiry into such concomitancies seems to be unavailable" (Malkiel 1967: 1228) "multiple causation is rarely suggested” (Thomason \& Kaufman 1988: 59).

${ }^{11}$ See Chamoreau \& Goury (2012) as recent examples.
} 
fictional narratives. With regard to internal factors, she finds that a specialized verbal form expressing mediated information in the narratives has relatively little functional rendering, given that Pomak has other means to delimit the fictional narrative frame, namely the temporal subordinators formed with deictic suffixes. With regard to language-contact factors, in a macro-linguistic perspective the passage from a marked to an unmarked mediate information expression in Pomak parallels the spread of trilingualism (with Greek and Turkish), affecting not only the society and its institutions as a whole but also individual trilingualism.

Lastly, with respect to the relationship between variation and change, Adamou notes that the change in the expression of mediate information in Pomak is attested over three generations, passing through a variation stage for the middle generation, depending on syntactic, semantic, and discursive parameters. Comparison with a 40-year-old corpus shows that variation between two forms already existed, even though the relevant factors are not the exact ones observed today. This indicates that by the 1960s variation had already begun to develop and that it became generalized over time until it led to the exclusive use of the perfect paradigm. The available data show that the variation probably started with the increased predominance of Greek and was facilitated by the loss of the oral tradition and lack of standardization practices. The rapidity of the variation stage seems to be related to the intensity of language contact.

$* * * *$

This volume offers a rich panorama of case studies and approaches dealing with linguistic variation in contact settings. Some chapters look at monolingual data, tracing variation and contact beneath surface homogeneity; others deal with apparent heterogeneity, such as codeswitching, or multilingual data showing variation, and trace the underlying regularities. A wide range of languages is discussed: Pomak, Turkish, and Greek, French and Guianese French Creole, Bislama and Tamambo, French and English, Russian and Estonian, American Spanish in contact with Amerindian languages such as Quechua and Guarani, several Northern Eurasian languages including Sakha, Evenki, and Yakut, and African languages such as Pana and Northern Samo. The chapters in the first part of the book extensively study linguistic variation and the spreading of variants or innovations in contact settings. They remind us how vivid variation is throughout languages in contact settings, and also what an important contribution to the field of language contact has been made by sociolinguistic studies on variation. Meyerhoff shows how the use of statistics and search for constraints on variation leads to defining different categories of language transfer. Blondeau outlines contact dynamics over time and space in Canada and the role of L2 speakers in the diffusion of change. Zabrodskaja also illustrates the role of code-switching in 
propagating innovation leading to change, and Beyer and Schreiber point to the role of innovative speakers as driving forces of change and to the role of mobility and kinship ties in multilingualism and the spread of variation and change.

The chapters in the second part of the book illustrate the important role of internal and ongoing variation when language change occurs in contact settings. Many contributors demonstrate the impact of language contact on pre-existing variation: as a catalyst (Adamou), producing a snowball effect (Zabrodskaja, Léglise), or activating or enhancing the frequency of some variants (Blondeau, Léglise, Pakendorf, Palacios). In these cases of internal variation pre-dating contact, one of the roles of ongoing variation is to provide the form (an already existing variant), which then becomes the norm within the speech community once the change is completed. In another instance, reported by Léglise, the effect of ongoing variation is to "give access" to some specific already non-stable grammatical zones. In this case, the role of language contact may be to enhance the productivity of variation within the zone. This may lead to the reorganization of a paradigm and appearance/disappearance of forms, or probably to what Pakendorf calls “exaptation." In yet another instance, ongoing variation may provide the material basis for grammaticalization processes, as in contact-induced exaptation, when existing forms are taken over to fulfill different functions from their original ones (Pakendorf).

As we address the complexity of language contact settings, the complexity of changes in contact settings, and the interplay of variation and change in contact settings, we need to read our data through equally complex lenses and work to refine our models. It is our hope that this volume will help to advance that project.

\section{References}

Aceto, M. 1999. Looking beyond decreolization as an explanatory model of language change in creole-speaking communities. JPCL 14(1): 93119.

Aitchison, J. 1991. Language Change: Progress or Decay? Cambridge: Cambridge University Press.

Aikhenvald, A. 2002. Language contact in Amazonia. Oxford: Oxford University Press

Aikhenvald, A. 2006. Grammars in Contact: A Cross-Linguistic Perpective. In Grammars in Contact: A Cross-Linguistic Typology, A. Aikhenvald \& R.M.W. Dixon (eds), 1-66. Oxford: Oxford University Press.

Auer, P. 1995. The pragmatics of code-switching: a sequential approach. In One speaker, two languages: cross-disciplinary perspectives on code- 
switching, L. Milroy \& P. Muysken (eds), 115-135. Cambridge: Cambridge University Press.

Auer, P. (ed.). 1998. Code-switching in conversation. Language, interaction and identity. London/New York: Routledge.

Auer, P. 1999. From codeswitching via language mixing to fused lects: Toward a dynamic typology of bilingual speech. The International Journal of Bilingualism 4: 309-332.

Auer, P. Hinskens F. \& Kerswill P. (eds). 2005. Dialect change: convergence and divergence in European languages. Cambridge: Cambridge University Press.

Bayley, R. \& Preston D. 1996. Second language acquisition and linguistic variation. Amsterdam: John Benjamins.

Béniak, E. \& Mougeon, R. 1984. Possessive à and de in Informal Ontarian French. In Papers from the XIIth Linguistic Symposium on Romance Languages, P. Baldi (ed.), 15-37. Amsterdam: John Benjamins.

Béniak, E. \& Mougeon, R. 1989. Recherches sociolinguistiques sur la variabilité en français ontarien. In Le français canadien parlé hors Québec, R. Mougeon \& E. Beniak (eds), 43-74. Québec: Presses de l’Université Laval.

Chamoreau, C. \& Goury, L. (eds). 2012. Changement linguistique et langues en contact. Paris: CNRS Editions.

Chamoreau, C. \& Léglise, I. 2012. A multi-model approach to contactinduced language change. In Dynamics of contact-induced language change, C. Chamoreau \& I. Léglise (eds), 1-16. Berlin: Mouton de Gruyter.

Chaudenson, R. 1986. Français marginaux, français zéro, créolisation. Aixen-Provence: Publication de l'Université de Provence.

Clark, R. 1994. The Polynesian outliers as a locus of language contact. In Language contact and change in the Austronesian world, T. Dutton \& D.T. Tryon (eds), 109-40. Berlin: Mouton de Gruyter.

Clyne, M. 1987. Constraints on code switching: how universal are they? Linguistics 25: 739-764.

Coseriu, E. 1958. Sincronia, diacronia e historia, El problema del cambio lingüistico. Montevideo.

Croft, W. 2000. Explaining Language Change. Harlow: Longman Linguistics Library.

De Camp, D. 1971. Toward a generative analysis of a post-creole speech continuum. In Pidginization and creolization of languages, D. Hymes (ed.), 349-370. Cambridge: Cambridge University Press.

Denison, D. 2003. Log(ist)ic and Simplistic S-Curves. In Motives for Language Change, R. Hickey (dir.), 54-70. Cambridge: Cambridge University Press.

Desagulier, G. 2005. Modélisation cognitive de la variation et du changement linguistiques : Étude de quelques cas de constructions 
émergentes en anglais contemporain. Thèse de doctorat, Université Bordeaux 3.

Farrar, K. \& Mari Jones, C. 2002. Introduction. In Language Change. The interplay of internal, external and extra-linguistic factors, C. J. Mari \& E. Esch (eds), 1-16. Berlin/New York: Mouton de Gruyter.

Fishman, J. 1967. Bilingualism with and without diglossia; diglossia with and without bilingualism. Journal of Social Issues 3: 29-38.

Kroch, A. 1989. Reflexes of Grammar in Patterns of Language Change. Language Variation and Change 1: 199-244.

Goury, L. \& Léglise, I. 2005. Contacts de créoles et créoles en contacts, Présentation. Etudes créoles XXVII (2): 9-19.

Gumperz, J. 1958. Dialect Differences and Social Stratification in a North Indian Village. American Anthropologist, New Series 60(4): 668-682.

Gumperz, J. 1982. Discourse Strategies. Cambridge: Cambridge University Press.

Heine, B. \& Kuteva, T. 2005. Language Contact and Grammatical Change. Cambridge: Cambridge University Press.

Houdebine, A.-M. 1985. Pour une linguistique synchronique dynamique. La linguistique 21: 7-36.

Israel, M. 1996. The Way Constructions Grow. In Conceptual Structure, Discourse and Language, A. E. Goldberg (ed.), 217-230. Stanford: CSLI Publications.

Johanson, L. 2002. Contact-induced change in a code-copying framework. In Language change: the interplay of internal, external, and extralinguistic factors, M.C. Jones \& E. Esch (eds), 285-313. Berlin/New York: Mouton de Gruyter.

Joseph, B. 1981. Multiple causation in Language Contact Change. Paper presented at Tenth Annual UWM Linguistics Symposium on Language Contact. Educational Resources Information Center Database, Claringhouse on Languages and Linguistics, doc. \#ED205021.

Kerswill, P. \& Williams, A. 2000. Creating a new town koiné: Children and language change in Milton Keynes. Language in Society 29: 65-115.

Labov, W. 1966. The Social Stratification of English in New York City Department Stores. Washington: Center for Applied Linguistics.

Labov, W. 1972. Language in the Inner City: studies in the black English vernacular. Philadelphia: University of Pennsylvania Press.

Labov, W. 1994. Principles of Linguistic Change. Vol. 1: Social Factors. Oxford: Blackwell.

Lass, R. 1988. How to do things with junk: exaptation in language evolution. Stellenbosch papers in linguistics (SPIL): 33-61.

Lauttamus, T. 1991. Borrowing, code-switching and shift in language contact: evidence from Finnish-English bilingualism. In Language Contacts East and West, M. Ojanen \& M. Palander (eds), 32-53. Joensuu: Joensuun yliopiston monistuskeskus. 
Léglise, I. 2007. Explaining language contact phenomena in a prospective diachronic perspective: discussion of a methodological frame. Language Contact Symposium, 10-13 mai, Max Planck Institut, Leipzig.

Lehmann, C. 1985. Grammaticalization: synchronic variation and diachronic change. Lingua e Stile 20: 303-318.

Malkiel, Y. 1967. Multiple versus simple causation in linguistic change. To Honor Roman Jakobson II, 1228-1246. The Hague: Mouton.

Martinet, A. 1955, Economie des changements phonétiques: traité de phonologie diachronique. Bern: A. Franke.

Matras, Y. 2007. The borrowability of structural categories. In Grammatical borrowing in cross-linguistic perspective, Y. Matras \& J. Sakel (eds), 31-73. Berlin: Walter de Gruyter.

Matras, Y. \& Sakel, J. (eds). 2007. Grammatical borrowing in crosslinguistic perspective. Berlin: Walter de Gruyter

Meillet, A. 1912. Introduction à l'étude comparative des langues indoeuropéennes. Paris: Hachette et cie.

Mesthrie, R. 1993. Koinéization in the Bhojpuri-Hindi diaspora, with special reference to South Africa. International Journal of the Sociology of Language 99: 25-44.

Meyerhoff, M. 2000. The emergence of creole subject-verb agreement and the licensing of null subjects. Language Variation and Change 12(2): 203-230.

Meyerhoff, M. \& Nagy, N. 2008. Introduction. Social lives in language. In Social lives in language. Sociolinguistics and multilingual speech communities, M. Meyerhoff \& N. Nagy (eds), 1-16. Amsterdam: John Benjamins.

Migge, B. \& Léglise, I. 2011. On the emergence of new language varieties: The case of the Eastern Maroon Creole in French Guiana. In Variation in the Caribbean, L. Hinrichs \& J. Farquharson (coords), 181-199. Amsterdam: John Benjamins.

Milroy, L. 2001. Social networks. In Handbook of Variation and Change, J. Chambers, P. Trudgill \& N. Schilling-Estes (eds), 549-72. Oxford: Blackwell.

Milroy, J. \& Milroy, L. 1985. Linguistic change, social network and speaker innovation. Journal of Linguistics 21(2): 339-384.

Milroy, J. \& Milroy, L. 1993. Mechanisms of change in urban dialects: The role of class, social network and gender. International Journal of Applied Linguistics 3(1): 57-77.

Mufwene, S. 2001. Creolization is a social, not a structural process. In Degrees of restructuring in Creole languages, I. Neumann-Holzshuh \& E.W Schneider (eds), 65-84. Amsterdam: John Benjamins.

Muysken, P. 2000. Bilingual Speech. A Typology of Code-mixing. Cambridge: Cambridge University Press. 
Myers-Scotton, C. 1993a. Social motivations for code switching: evidence from Africa. Oxford: Oxford University Press.

Myers-Scotton, C. 1993b. Duelling languages: grammatical structures in codeswitching. Oxford: Clarendon Press.

Nichols, J. 1992. Linguistic Diversity in Space and Time. Chicago: University of Chicago Press.

Poplack, S. 1980. Sometimes I'll start a sentence in English Y TERMINO EN ESPAŇOL: towards a typology of code-switching. Linguistics 18 (7/8): 581-618.

Ross, M. 1997. Social networks and kinds of speech community events. In Archaeology and Language, Vol. 1: Theoretical and methodological orientations, M. R. Blench and M. Spriggs (eds), 209-261. London: Routledge.

Sankoff, G. 2002. Linguistic Outcomes of Language Contact. In The Handbook of Language Variation and Change, J.K. Chambers, P. Trudgill \& N. Schilling-Estes (eds), 638-668. Oxford: Blackwell.

Schwegler, A. 1983. Predicate negation and word-order change: A problem of multiple causation. Lingua 61(4): 297-334

Siegel, J. 1987. Language Contact in a Plantation Environment. Cambridge: Cambridge University Press.

Stolz, Thomas, 2006, Contact-induced typological change. In Marginal Linguistic Identities. Studies in Slavic Contact and Borderland Varieties, D. Stern \& S. Voss (eds), 14-30. Wiesbaden: Harrassowitz Verlag.

Thomason, S.G. 2001a. Language contact: an introduction. Edinbourg: Edinburg University Press.

Thomason, S.G. 2001b. Contact-induced typological change. In Language typology and language universals, Sprachtypologie und sprachliche Universalien,Volume 2, 2. Halbband, Tome 2, M. Haspelmath, E. Koenig, W. Oesterreicher \& W. Raible (eds), 1640-1648. Berlin/New York: Walter de Gruyter.

Thomason, S.G. \& Kaufman, T. 1988. Language contact, creolization, and genetic linguistics. Berkeley: University of California Press.

Tsitsipis, L. D. 1998. A linguistic anthropology of praxis and language shift: Arvanı'tika (Albanian) and Greek in contact. Oxford: Clarendon Press.

Trudgill, P. 1974. The social differentiation of English in Norwich. Cambridge: Cambridge University Press.

Trudgill, P. 1986. Dialects in contact. Oxford: Blackwell.

Trudgill, P. 1999. New-dialect formation and dedialectalisation: embryonic and vestigial variants. Journal of English Linguistics 27: 319-327.

Trudgill, P. 2004. Linguistic and social typology: the Austronesian migrations and phoneme inventories. Linguistic Typology 8: 305-320.

Valli, A. 2001. Sur quelques types d'hétérogénéité des structures grammaticales en français. Tranel 34-35: 117-130. 
Weinreich, U. 1953. Languages in Contact: Findings and Problems. New York. [Reprint 1963. The Hague: Mouton]

Weinreich, U., Labov, W. \& Herzog, M. 1968. Empirical foundations for a theory of language change. In Directions for Historical Linguistics, W.P. Lehmann \& Y. Malkiel (dirs), 95-185. Austin: University of Texas Press.

Winford, D. 1997. Creole formation in the context of contact linguistics. Journal of Pidgin and Creole Languages 12: 131-151.

Winford, D. 2003. An introduction to contact linguistics. Oxford: Blackwell. 